\title{
Article \\ Physiological and Molecular Characterization of New Apricot Cultivars Grafted on Different Prunus Rootstocks
}

\author{
Patricia Irisarri ${ }^{1,2}(\mathbb{D})$, Pilar Errea ${ }^{1,2}$ and Ana Pina $1,2, * \mathbb{D}$ \\ 1 Unidad de Hortofruticultura, Centro de Investigación y Tecnología Agroalimentaria de Aragón (CITA), Avda, \\ Montañana 930, 50059 Zaragoza, Spain; pirisarri@aragon.es (P.I.); perrea@aragon.es (P.E.) \\ 2 Instituto Agroalimentario de Aragón-IA2, CITA-Universidad de Zaragoza, 50013 Zaragoza, Spain \\ * Correspondence: apina@aragon.es
}

Citation: Irisarri, P.; Errea, P.; Pina,

A. Physiological and Molecular

Characterization of New Apricot Cultivars Grafted on Different Prunus Rootstocks. Agronomy 2021, 11, 1464. https://doi.org/10.3390/agronomy 11081464

Academic Editor: Gemma Reig

Received: 23 June 2021

Accepted: 20 July 2021

Published: 23 July 2021

Publisher's Note: MDPI stays neutral with regard to jurisdictional claims in published maps and institutional affiliations.

Copyright: (c) 2021 by the authors. Licensee MDPI, Basel, Switzerland. This article is an open access article distributed under the terms and conditions of the Creative Commons Attribution (CC BY) license (https:// creativecommons.org/licenses/by/ $4.0 /)$.

\begin{abstract}
In the last years, an important renewal of plant material from different breeding programs is taking place in apricot in order to improve resistance to biotic stresses, extension of the harvest season, fruit quality, and productivity. However, the graft compatibility of many of these cultivars with most popular Prunus rootstocks is unknown, and this is an essential agronomical trait for their better performance and longevity. Hence, the introduction of new cultivars requires knowledge of the extent and nature of incompatibility reactions before releasing these cultivars on the market. In this study, the determination of graft compatibility was carried out in 13 new apricot cultivars grafted on four Prunus rootstocks: 'Marianna2624' (P. cerasifera $\times$ P. musoniana), 'Miragreen' (P. cerasifera $\times$ P. davidiana), 'Mirared' (P. cerasifera $\times$ Nemared), and 'Montclar' (P. persica L. seedlings) at early stages of development. By combining cytomorphological, anatomical, and phenylalanine ammonia-lyase (PAL) gene expression analysis at the graft interface, as well as different vegetative parameters, the results highlighted 'Miragreen' and 'Mirared' as promising rootstocks for apricot, showing the highest degree of compatibility with more than $90 \%$ of the apricot cultivars. These results provide useful information for breeders and growers by selecting the most suitable scion-rootstock for efficient orchard design by planting compatible graft combinations.
\end{abstract}

Keywords: graft compatibility; histology; PAL; Prunus armeniaca L.; scion-rootstock interaction

\section{Introduction}

Apricot (Prunus armeniaca L.), which belong to the Rosaceae family, is one of the most popular stone fruit crops with a total world production of 4.25 million tons [1]. Europe has $23.42 \%$ of world production, and Spain is the second European producer and seventh worldwide [1]. The fruit is flavorful, easy to eat, and has many forms to be eaten [2], but the production is restricted because apricot requires specified eco-climatic conditions [3]. The growth of apricot production is changing due to globalization and changes in the economic factors that depend on market requirement, virus (sharka caused by Plum Pox Virus) and bacterial diseases (Pseudomonas spp. and Xhanthomonas arboricola pv. pruni), and costs of labor and adaptability to the environment (cold and warm areas, water deficit) [2,3]. In recent years, an important renewal of plant material has been taking place in apricot, with the introduction of new cultivars from different breeding programs [2,4-7]. The introduction of these new apricot cultivars from private and publicly funded apricot breeding programs are improving apricot culture, resistance to biotic stresses, extension of the harvest season, fruit quality for fresh consumption and for processing, productivity, and tree size and structure [2,8]. However, the agronomical behavior of these new cultivars in different soil and climatic conditions of Spain is unknown. Therefore, several factors should be considered when selecting an apricot cultivar, including local climate, chilling necessities, flower, ripening, and graft compatibility with common rootstocks adapted to our area conditions. The graft compatibility of many of these cultivars with most popular 
Prunus rootstocks is unknown, but this is an essential factor for their better performance and longevity [9].

Several investigations have been performed in the rootstock research and breeding for apricot [10]. Primary targets of rootstock selection for apricot are scion vigor, fruit size, yield, tree longevity, precocity, rootstock vigor, graft compatibility, disease/pest resistance; abiotic tolerance (salt, cold) [2,11]. Despite the fact that apricot can be grown successfully on rootstocks of other species within the Prunus genus, including peach, plum, and various interspecific Prunus hybrids, the number of species used as rootstocks for apricot is not large due to graft affinity. Indeed, the widespread use of some Prunus spp. for apricot production is the lack of commercial rootstocks having a wide range of compatibility with all cultivars [12,13]. In general, the graft compatibility behavior of these species is not homogeneous for apricot cultivars, and some of them present graft incompatibility symptoms with some of the most used rootstocks. Therefore, to choose the right rootstock, it is important to take into account rootstock-scion affinity, as well as the adaptation for different soil types and climatic conditions.

Graft compatibility is a complex agronomic trait that produces a wide range of different physiological, biochemical, and anatomical interactions throughout graft development. The graft process starts with the adhesion between grafted partners and subsequent callus formation, followed by establishment of new vascular tissue and the formation of a functional vascular system across the graft [14-16]. The graft behavior of apricot cultivars grafted in the most popular Prunus rootstocks is different depending on the scion-rootstock interactions, resulting in solid unions or, on the contrary, showing incompatible symptoms. In these combinations, incompatible unions are characterized by anatomical discontinuities at the graft interface accompanied by poor vascular connections, leading to mechanical weakness and subsequent breakdown of the graft union that can take years to manifest [17-19]. For this reason, reliable and short-term studies are necessary for early selection of new cultivars and rootstocks to be released into the market. In this regard, several approaches have been applied to study the graft process at early stages of development in order to forecast the fate of a successful graft [13,18-21]. Histological techniques have been used for visualization of the first stages of graft development, such as plasmodesmata formation, callus organization, program cell death (PCD), and X-ray tomography [22-26]. In addition, several studies have revealed molecular changes between compatible and incompatible unions [26-30]. Different metabolic pathways have been involved in the incompatibility reaction, such as phenylpropanoid pathway, oxidative stress, and defense responses (reviewed by Pina, A. [21]; Loupit, G. [29]; Assunção, M. [31]). In stone fruit trees, phenylalanine ammonia lyase (PAL) genes were shown to be differentially regulated between compatible and incompatible unions [30,32,33], which play an important role in many development aspects of plant growth [34-36]. In incompatible grafts, an increase of PAL enzyme expression has been associated with a lack of adaptation between both graft partners $[27,32,33]$. On the other hand, there are many studies about the accumulation of phenolic compounds in graft unions showing different compatibility degrees, not only in apricot [37-40]. Likewise, differential gene expression changes related with cellular cycle, signal transduction, cell wall modifications, and hormonal signal have been observed during graft union development [41,42]. At the genetic level, two genomic regions on LG5 $(44.9-60.8 \mathrm{~cm})$ and LG8 $(33.2-39.2 \mathrm{~cm})$ were recently associated with graft (in)compatibility in apricot [43]. QTLs with a significant effect through the years were found in LG8, as well as suggestive QTLs on LG5. More research efforts are focused now on non-destructive methods for graft compatibility prediction with the identification of molecular markers that could forecast compatibility without the need for grafting [29,31,43].

The objective of this work was to evaluate the graft compatibility of 13 apricot cultivars from different breeding programs when grafted into four genetically different Prunus rootstocks ('Marianna 2624', 'Montclar', 'Mirared', and 'Miragreen'. Some of them are recently being introduced in the region of Aragon due to their good affinity with some apricot cultivars and resistance to several diseases, but the graft compatibility of these 
rootstocks with the new apricot cultivars is completely unknown. For this reason, graft compatibility was phenotyped in these new graft combinations at early stages of graft development combining histological, molecular, and anatomical analysis. The presented results will determine the best cultivar for every rootstock and provide useful information for breeders and growers by selecting the most suitable scion-rootstock combinations and for efficient orchard design by planting compatible apricot-grafted combinations.

\section{Materials and Methods}

\subsection{Plant Material}

The plant material for this study included 11 apricot cultivars (Table 1) of recent introduction and unknown behavior to the graft and two traditional apricot cultivars 'Paviot' and 'Moniqui' used as graft controls with the rootstock 'Marianna 2624'. 'Paviot' was considered a compatible cultivar, whereas 'Moniqui' was considered to express graft incompatibility when grafted to plum rootstocks [17].

Table 1. Origin, breeding program, and bloom characteristics of the 13 cultivars used in this study.

\begin{tabular}{|c|c|c|c|c|}
\hline \multirow{2}{*}{ Cultivars } & \multirow{2}{*}{ Origin } & \multirow{2}{*}{ Breeding Program } & \multicolumn{2}{|c|}{ Bloom } \\
\hline & & & Season & Fertility \\
\hline Moniqui & Spain & Traditional & early & sterile \\
\hline Paviot & France & Traditional & late & self fertile \\
\hline Playa Cot & France & COT international & late & self fertile \\
\hline Swired & SUISSE & COT international and STAR FRUITS & semi early & self fertile \\
\hline Delice Cot & France & COT international & semi-late & self fertile \\
\hline Maya Cot & France & COT international & early & sterile \\
\hline Rouge Cot & France & COT international & semi late & self fertile \\
\hline Monster Cot & EEUU & $\begin{array}{l}\text { SMS UNLIMITED-USA California COT } \\
\text { international }\end{array}$ & medium & self sterile \\
\hline Farbela (cov) & France & Newcot (International Plant Selection) & early & self fertile \\
\hline Farlis (cov) & France & Newcot (International Plant Selection) & late & self fertile \\
\hline M016 & Advanced selection & Advanced selection & Advanced selection & Advanced selection \\
\hline Holly Cot & France & COT international & early & self sterile \\
\hline Farclo (cov) & France & Newcot (International Plant Selection) & medium & self fertile \\
\hline
\end{tabular}

These cultivars were grafted on four rootstocks: 'Marianna2624' (Prunus cerasifera $\times$ Prunus musoniana, hereafter referred to as 'MN2624'), 'Miragreen' (P. cerasifera $\times P$. davidiana), 'Mirared' (P. cerasifera $\times$ Nemared), and 'Montclar' (Prunus persica L. seedling) in a nursery located at the Viveros Mariano Soria S.L. in La Almunia-Cariñena, km 4800 Zaragoza, Spain $\left(41^{\circ} 28^{\prime} 37.4^{\prime \prime} \mathrm{N} 1^{\circ} 22^{\prime} 26^{\prime \prime} \mathrm{W}\right)$. The branches were collected with a $5 \mathrm{~mm}$ diameter in January 2017 and kept in a chamber under controlled conditions $\left(4^{\circ}\right)$ until grafting in spring of the same year. The rootstocks were one-year-old plants with a diameter of $1 \mathrm{~cm}$, and 24 grafts per combination were performed by chip-budding. These grafts were phenotyped for graft compatibility by (1) microscope observations at 42 days after grafting (DAG), (2) vegetative and molecular analysis three months after grafting, and (3) anatomical evaluation one year after grafting (Figure 1). 


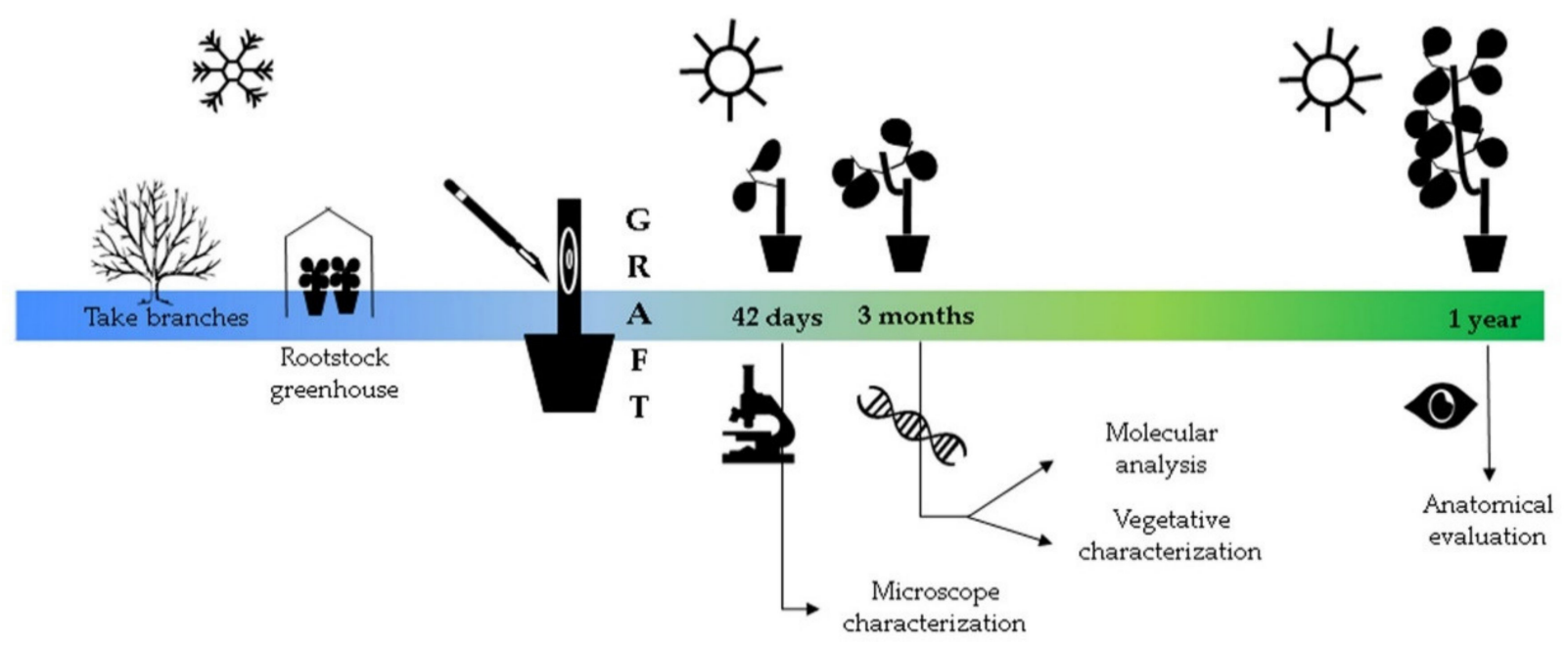

Figure 1. Time line of experimental design to determine graft compatibility during one year.

\subsection{Cytomorphological Characterization $42 D A G$}

Grafts were cut $1 \mathrm{~cm}$ above and below the graft union $42 \mathrm{DAG}$, fixed in ethanol $(96 \%) /$ acetic acid $3: 1(\mathrm{v} / \mathrm{v})$ over $24 \mathrm{~h}$, then transferred to ethanol $(70 \%)$ and stored at $4{ }^{\circ} \mathrm{C}$ for conservation [44]. Longitudinal free-hand sections were obtained from the surface of the graft in all unions with a high-profile microtome blade (Feather Japan). The internal characterization of the graft union was carried out according to Irisarri [45] using a stereomicroscope (Figure 2A). The longitudinal sections were transferred into Petri dishes and stained for $30 \mathrm{~s}$ with cellulose-specific dye solution in distilled water $0.07 \%(w / v)$. The sections were observed using an Olympus BH2-RFCA fluorescence microscope equipped with a digital imaging system through a USB 2 uEye SE camera (IDS, Obersulm, Germany). Three replicates were tested for every graft combination. Assignment of phenotypic scores to individuals was based on cell pattern, like cell arrangement, cell shape, and cell proliferation at the graft interface (Figure 2B). The classification was from 1, when the union was completely filled with ordered cells, to 5, when the space between scion-rootstock was practically empty.

\subsection{Vegetative amd Molecular Characterization 3 Months after Grafting}

The vegetative growth development of the different combinations was followed by the measurement of the graft length $(\mathrm{cm})$ and number of leaves. After that, the graft interface was taken with a scalpel, frozen in liquid nitrogen immediately, and stored at $-80{ }^{\circ} \mathrm{C}$ until RNA isolation. Total RNA was extracted using CTAB protocol adapted by Meisel [46]. All RNA samples were digested with turbo DNase (Ambion, CA, USA) to remove possible DNA contamination. We took $1 \mu \mathrm{g}$ of total RNA, and it was reverse transcribed with First Strand cDNA Synthesis kit (Thermo Scientific, CA, USA) according to the manufacturer's instructions. The real-time PCR (qPCR) was performed on a CFX96 TouchTM (Bio Rad, CA, USA) in a total volume of $10 \mu \mathrm{L}$ containing: $5 \mu \mathrm{L}$ of SYBR Green (Bio Rad, CA, USA), $4 \mu \mathrm{L}$ of diluted cDNA, and $300 \mathrm{nM}$ of each primer. RT-PCRs were carried out with the gene-specific primers as described by Irisarri [33] (Table 2). 


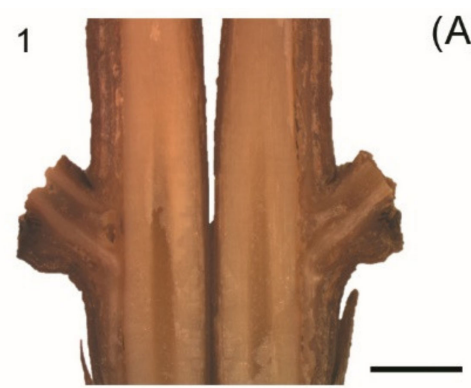

2

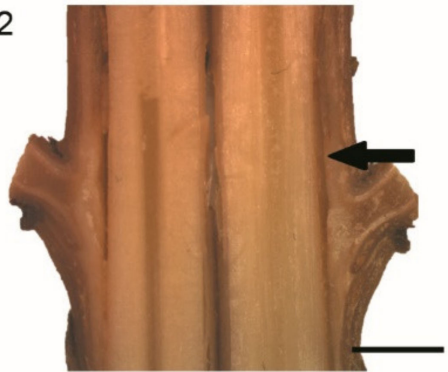

3

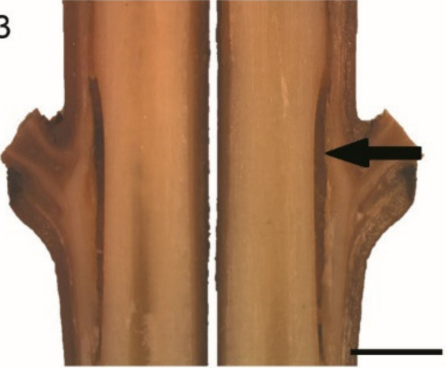

4

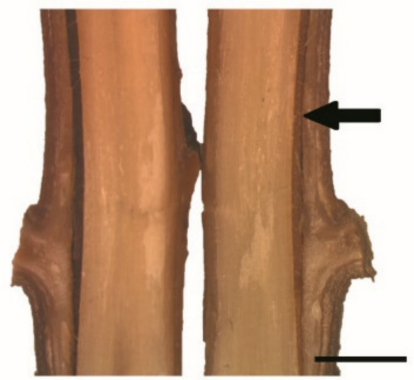

5
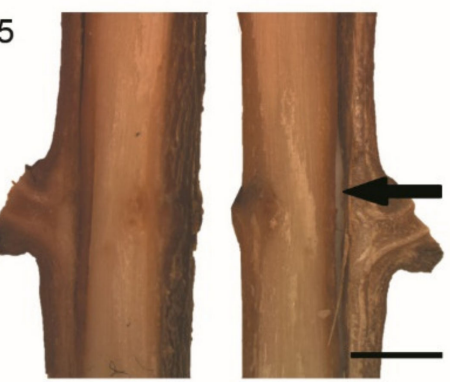

(A)
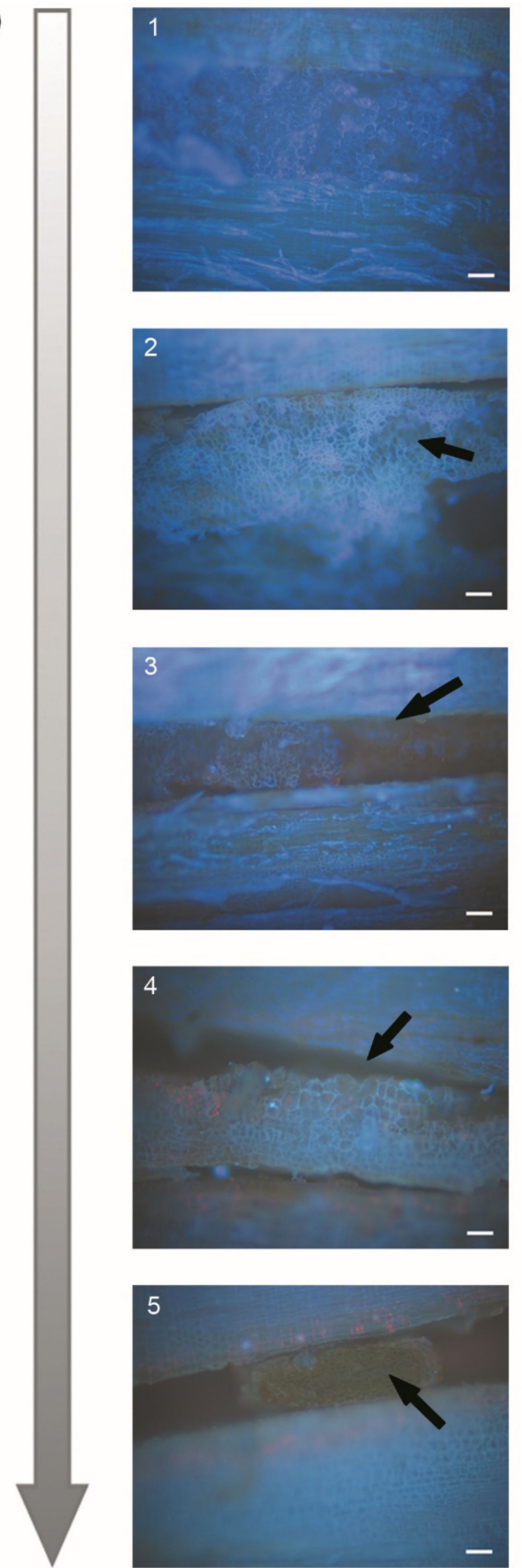

(B)

Figure 2. Phenotypic scoring from compatible to incompatible graft combinations. (A) Category representation for the stereomicroscope from $1=$ absence necrosis (graft compatible plants) to $5=$ maximum level of necrosis (graft incompatible plants). Black arrows show the necrotic line $($ Bars $=2 \mathrm{~mm})($ B) Microscope classification at the graft interface after staining with calcofluor $($ Bars $=200 \mu \mathrm{m})$. Different degree of callus cell proliferation the graft interface from score $1=$ compatible union to score $5=$ incompatible union. Numbers at the top right of the images indicate the phenotypic assignment. 
Table 2. Gene-specific primers and real-time amplification products for each gene.

\begin{tabular}{|c|c|c|c|c|c|}
\hline Primer Name & Primer Sequences $\left(5^{\prime}-3^{\prime}\right)$ & $\operatorname{Tm}\left({ }^{\circ} \mathrm{C}\right)$ & Amplicon Size (pb) & RT-qPCR Efficiency ${ }^{1}$ & $\mathbf{R}^{2 *}$ \\
\hline PAL1 (forward) & ATGAGGTGAAGCGCATGGTG & 62 & \multirow{2}{*}{85} & \multirow{2}{*}{1.941} & \multirow{2}{*}{0.9994} \\
\hline PAL1 (reverse) & CTATGGCAGCCACTTGGGAA & 62 & & & \\
\hline PAL2 (forward) & AGGTCAAACGGATGGTCAAC & 58 & \multirow{2}{*}{85} & \multirow{2}{*}{1.974} & \multirow{2}{*}{0.9995} \\
\hline PAL2 (reverse) & ATTGCAGCCACCTGAGCTAT & 60 & & & \\
\hline Actin (forward) & TGAGGCTCCTCTCAACCСТA & 62 & \multirow{2}{*}{82} & \multirow{2}{*}{1.978} & \multirow{2}{*}{0.9987} \\
\hline Actin (reverse) & ATACATGGCAGGCACATTGA & 58 & & & \\
\hline
\end{tabular}

The gene expression values were normalized to the actin gene from peach (GenBank accession number AB046952) and were depicted relative to the values of the corresponding controls (ungrafting rootstocks). Fluorescence values were baseline-corrected and averaged efficiencies for each gene and $\mathrm{Ct}$ values were calculated using LinRegPCR program [47]. Gene expression measurements were determined with the Gene Expression Ct Difference (GED) formula $[48,49]$. In all experiments, negative controls (no templates) were subjected to the same procedure that detects and prevents any possible contamination. Each sample was analyzed in three replicates, and reactions were repeated three times to verify reproducibility.

\subsection{Anatomical Observations One Year after Grafting}

The graft interface diameter of every graft combination was measured with a digital caliper (Mitutoyo, Kawasaki, Japan), and 10 leaves of each cultivar were collected to measure their area by scanning and subsequent analysis with the package LeafArea using ImageJ software (NIH, Denvor, CO, USA, http:/ /imagej.nih.gov/ij/, accessed on 23 July 2021) to run within R software (ver. 3.5.0; R Core Team, 2017) [50]. After growth measurement one year after grafting, grafts were cut $5 \mathrm{~cm}$ above and $5 \mathrm{~cm}$ below the union. The internal characterization of the graft union was carried out through a longitudinal cut at the graft area with a DW876 saw (Dewalt, Perugia, Italy). Anatomy on the surface of the union was observed using a stereomicroscope (Wild Heerbrugg, Heerbrugg, Switzerland) equipped with a digital imaging system through a USB 2uEye SE camera (IDS, Obersulm, Germany). The evaluation was performed according to Herrero categories [51]. Each individual combination was classified according to the graft union line, in five categories (A-E). 'A' represents a perfect union in which the graft line is almost invisible. 'B' has some structural defects with slight discontinuity between the wood and the bark or involution of the cambium in the graft interface. ' $C$ ' is characterized by an evident layer of parenchymal tissue in the wood and bark or in the union. ' $\mathrm{D}$ ' has discontinuities in practically the entire line between scion and rootstock. Finally, ' $E$ ' is characterized by broken unions and dead tissue around the graft interface. When most of the unions of a cultivar are classified in ' $\mathrm{A}$ ' and ' $\mathrm{B}$ ', they can be considered compatible. However, if the majority are in ' $\mathrm{D}$ ' and ' $\mathrm{E}$ ', they are considered incompatible

\subsection{Statistical Analysis}

Statistical analysis was carried out with IBM SPSS Statistics 21 (SPSS Inc., Chicago, IL, USA). The data were tested for normality using the Shapiro-Wilk test and for homogeneity of variances with the Levene's test. A nonparametric test was performed and Kruskal-Wallis test (at $p<0.05)$ implemented in the SPSS package. In addition, Pearson correlation and principal component analysis (PCA) were performed to establish the relation between the different characters evaluated. While correlation was made with SPSS, PCA was made with the package ggplot2 and FactoMinerR from R environment [52]. 


\section{Results}

\subsection{Graft Take Rates and Cytomorphological Characterization at $42 D A G$}

A low degree of success in the early stages of the union process is one of the external symptoms that has been associated with incompatible graft unions in some woody species [14]. Graft take rates showed marked differences between the different scionrootstock combinations. Our results at 42 DAG suggested that grafting onto the rootstock 'MN2624' induced early sprouting of the majority scion genotypes (81\%), followed by the grafting onto 'Montclar' (78\%), 'Mirared' (75\%), and 'Miragreen' (62\%) (Table 3). In line with rootstocks, the success of graft take in 'MN2624' ranged from $100 \%$ (cvs 'Monster Cot' and 'Rouge Cot') to 50\% (cv. 'Paviot'), from 25\% (cv. 'Swired') to 100\% (cv. 'Playa $\mathrm{Cot}^{\prime}$ ) in 'Miragreen, from 38\% (cv. 'Holly Cot') to 100\% (cv. 'Playa') in 'Mirared', and from $44 \%$ (cv. 'Moniqui') to 100\% (cvs. 'Monster Cot' and 'M016') in 'Montclar'. Among the apricot cultivars, the cultivar 'Monster Cot' was one of the most successful cultivar with all rootstock $(90 \%)$, and 'Paviot' was the cultivar with the least graft take success (46\%) (Table 3).

Table 3. Percentage of graft take sprouting at 42 DAG in all combinations.

\begin{tabular}{cccccc}
\hline \multirow{2}{*}{ Cultivar } & \multicolumn{5}{c}{ Graft Take (\%) } \\
\cline { 2 - 5 } & 'MN2624' & 'Miragreen' & 'Mirared' & 'Montclar' & \\
\hline Moniqui & 67 & 50 & 67 & 44 & 57 \\
\hline Paviot & 50 & 42 & 58 & 58 & 52 \\
\hline Playa Cot & 67 & 100 & 100 & 75 & 85 \\
\hline Swired & 83 & 25 & 92 & 83 & 71 \\
\hline Delice Cot & 83 & 75 & 92 & 92 & 85 \\
\hline Maya Cot & 67 & 58 & 83 & 67 & 69 \\
\hline Rouge Cot & 100 & 75 & 92 & 67 & 83 \\
\hline Monster Cot & 100 & 75 & 83 & 100 & 90 \\
\hline Farbela (cov) & 83 & 50 & 67 & 75 & 69 \\
\hline Farlis (cov) & 83 & 67 & 58 & 83 & 73 \\
\hline M016 & 100 & 67 & 83 & 100 & 88 \\
\hline Holly Cot & 92 & 67 & 38 & 92 & 72 \\
\hline Farclo (cov) & 83 & 58 & 75 & 83 & 75 \\
\hline & 81 & 62 & 75 & 78 & \\
\hline
\end{tabular}

The cytomorphological characterization through histological analyses showed physiological differences between the different graft combinations at the graft interface. Different phenotypic traits were assessed such as necrosis line, callus cells proliferation, cell arrangement, and cellular shape related with the early steps of graft union development. The apricot cultivars 'Paviot' and 'Moniqui' were used as controls with strongly contrasting graft compatibility behavior, considered compatible and incompatible with the rootstock 'MN2624', respectively [24]. The phenotypic characterization of the graft interface allowed us to classify the 13 apricot cultivars into two main clusters (Figure 3), depending mainly on the observed phenotypic traits related to graft (in)compatibility for each rootstock. One cluster contained apricot cultivars showing an organized and homogeneous cell arrangement at the contact surface, strongly stained with calcofluor similar to the description of 'Paviot', and the other cluster displayed disorganized arrangement in some areas of the contact surface, showing no additional development similar to the incompatible cv. 'Moniqui' (Figure 3A). The percentage of apricot cultivars that clustered with 'Paviot' was $73 \%$ for the rootstocks 'Miragreen' and 'Mirared' and 54\% for 'MN2624' and 'Montclar'. In terms of 
graft compatibility, 'Miragreen' and 'Mirared' showed a wide range of compatibility with all cultivars, followed by 'Montclar', and 'MN2624' (Figure 3).

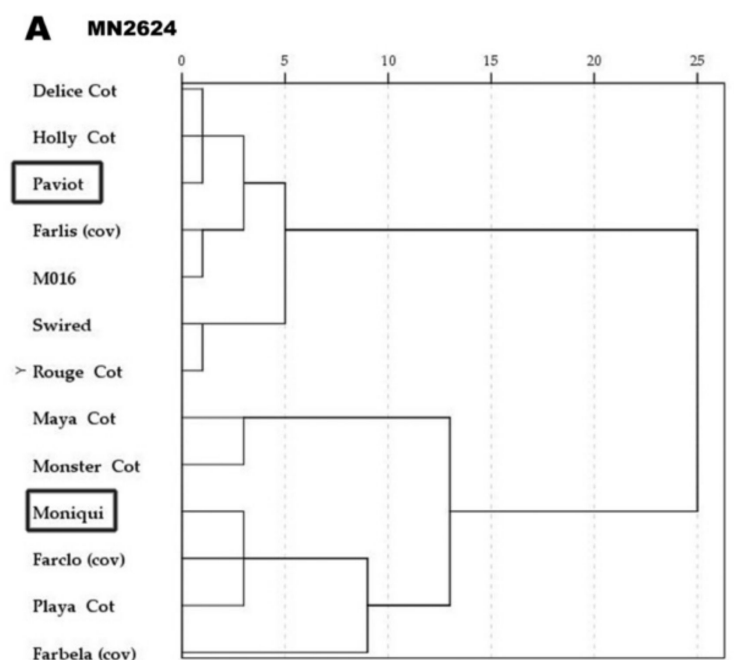

\section{Miragreen}

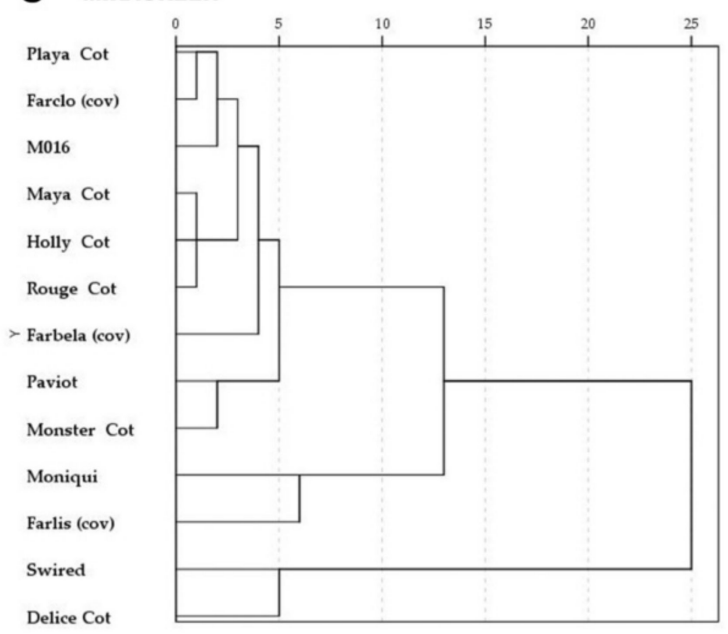

B MONTCLAR

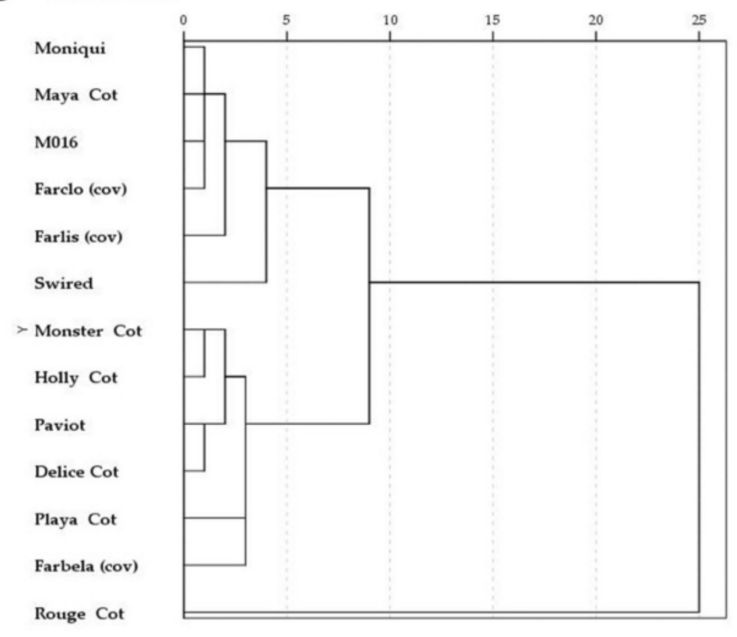

D MIRARED

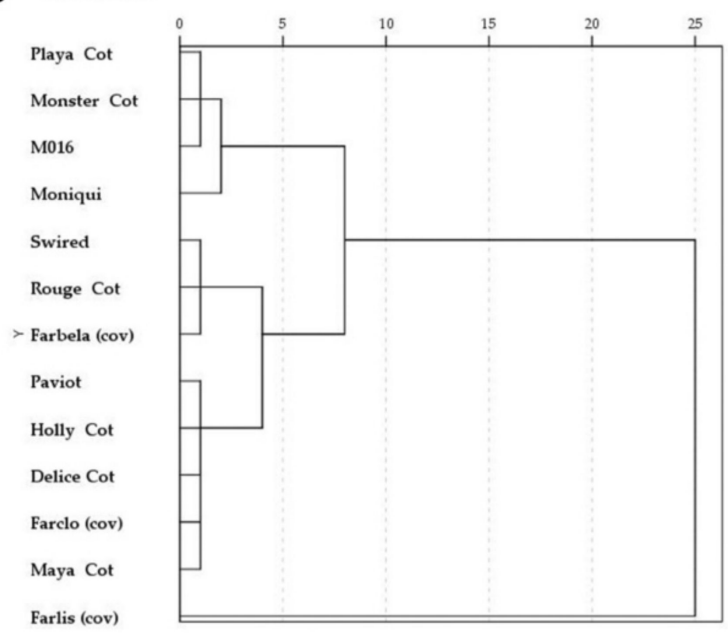

Figure 3. Dendrograms showing the distribution of the 13 apricot cultivars grafted on four different rootstocks: (A) 'MN2624', (B) 'Montclar', (C) 'Miragreen', and (D) 'Mirared' at 42 days after grafting. Dendrograms are based on the different histological characters evaluated: necrosis line, cell proliferation, cell arrangement, and cellular shape. The apricot cultivars 'Paviot' and 'Moniqui' were grafted on 'MN2624' and used as controls considered compatible and incompatible, respectively [24].

\subsection{Vegetative Growth and Molecular Characterization 3 Months after Grafting}

The vegetative growth was measured by graft length and number of leaves three months after grafting. The results showed that the effect of the rootstock on the scion growth parameters was related to the graft length but not to the number of leaves among graft combinations. Whereas non-statistical differences were found related to the graft length among the different apricot cultivars grafted on 'MN2624' and 'Miragreen' (Figure 4A,B), significant differences were observed within the rootstock 'Montclar' (Figure 4C) and 'Mirared' (Figure 4D). 'Monster Cot' and 'Moniqui' grafted on the rootstock 'Montclar' and 'Mirared' presented higher and lower values compared to the other graft combinations, respectively (Figure 4C,D). Likewise, significant differences were observed among graft combinations within each scion genotype. The apricot cultivars 'Swired', 'Farlis (cov)', 'M016', and 'Monster Cot' grafted on 'Montclar' and cv. 'Rouge Cot' when grafted on 'Mirared' showed a higher growth when compared with all the other rootstocks. For the remaining eight apricot cultivars, the different rootstocks did not cause significant effects 
on graft length. Indeed, 'Montclar' provided a higher growth in $69 \%$ of the cultivars (9 of 13 ), whereas 'MN2624' showed lower vegetative growth in $77 \%$ of the cultivars (10 of 13).
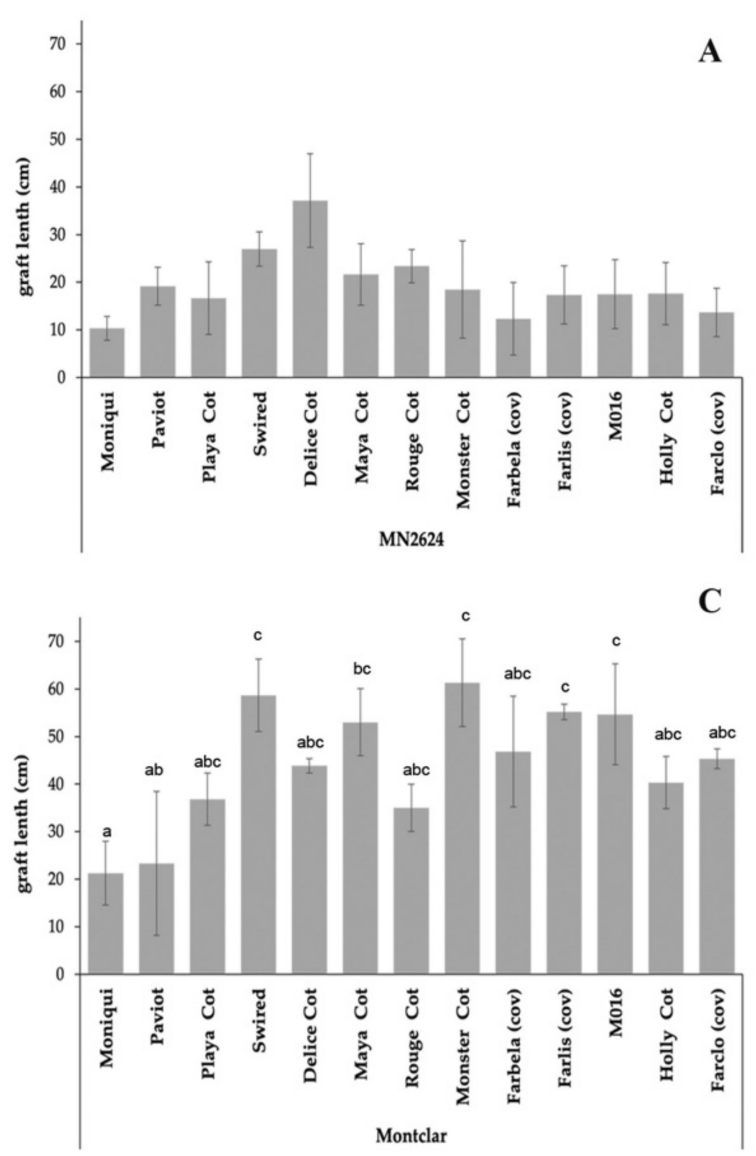

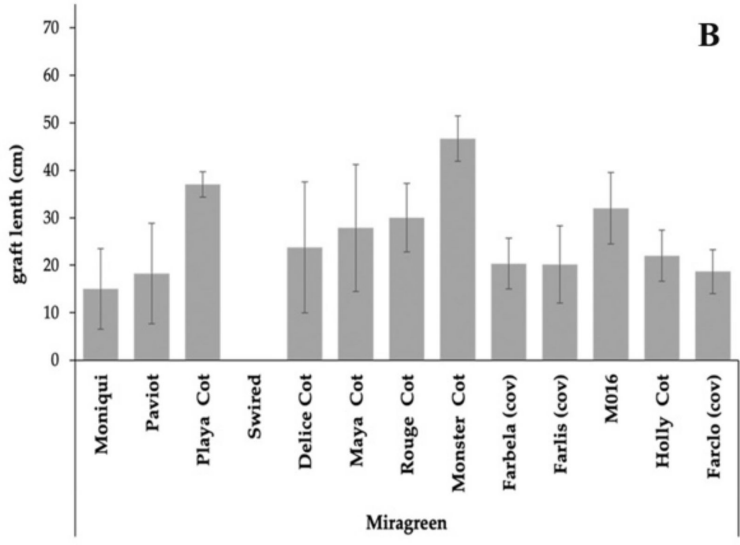

D

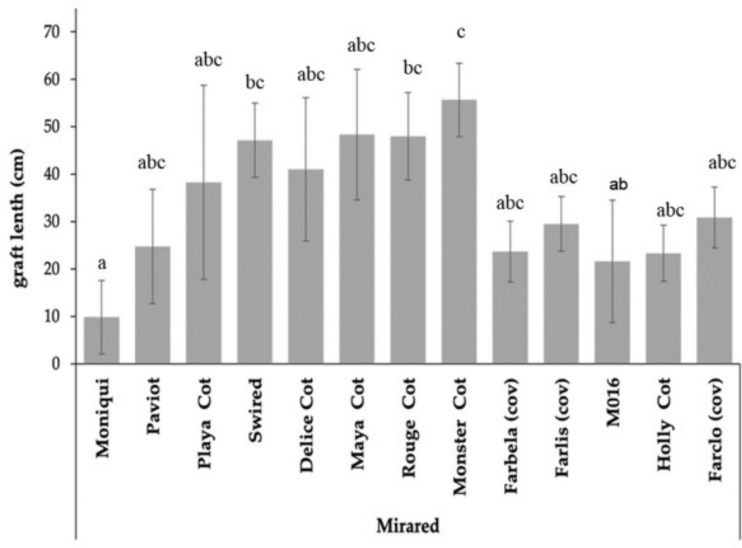

Figure 4. Evaluation of the graft length (cm) of 13 apricot cultivars grafted on four different Prunus rootstocks. (A) 'MN2624', (B) 'Miragreen', (C) 'Montclar', and (D) 'Mirared'. Values are means of three replicates \pm SE. Values followed by different letters within each cultivar for different rootstocks are significantly different at $p<0.05$ according to Kruskal-Wallis for independent samples.

In addition to the vegetative parameters, gene expression of PAL isoforms (PAL1 and PAL2) were measured by qRT-PCR in all different graft combinations; since differences in PAL gene expression were previously reported in apricot cultivars grafted on plum rootstocks showing localized incompatibility $[33,53]$. Whereas the results indicated that PAL genes had a similar steady state level in the apricot cultivars grafted on 'Miragreen' and 'Mirared', a higher expression level of PAL1 for the cultivars grafted on the 'Montclar' rootstock compared to the other rootstocks was obtained (Figure 5). The strongest signal for PAL 1 was detected for the cvs. 'Moniqui', 'Monster Cot', and 'Rouge Cot' grafted on 'MN2624', whereas the strongest signal for the rootstock 'Montclar' was observed in the cvs. 'Maya Cot', 'Monster Cot', and 'Holly Cot'. PAL 1 transcripts were approximately four-fold more abundant in the cv. 'Monster Cot' grafted on 'Montclar' compared to 'MN2624'. In 'Miragreen', PAL1 was more expressed in the cvs. 'Playa Cot' and 'Holly Cot' compared to the other graft combinations, whereas PAL1 gene had a similar steady state level in the cultivars grafted on 'Mirared'. Furthermore, it was shown that apricot cultivars grafted on 'Montclar' had a significant three-fold increase in PAL1 gene expression compared to the combinations with 'MN2624' and six-fold increase compared to'Mirared'. Likewise, the percentage of cultivars with the highest PAL1 expression for each rootstock was $77 \%$ for 'MN2624', 62\% for 'Montclar', 38\% for 'Miragreen', and $0 \%$ for 'Mirared'. Taken as a whole, physiological and molecular studies pointed out that 'Mirared' and 'Miragreen' presented a greater degree of compatibility with all apricot cultivars than when the same 
cultivars were grafted on the rootstocks 'MN2624'or 'Montclar'. For PAL2 gene expression, similar values were obtained between all graft combinations for the rootstocks 'MN2624' and 'Montclar' but with higher PAL 2 values in 'Miragreen' and 'Mirared', which might be related to lignification processes.

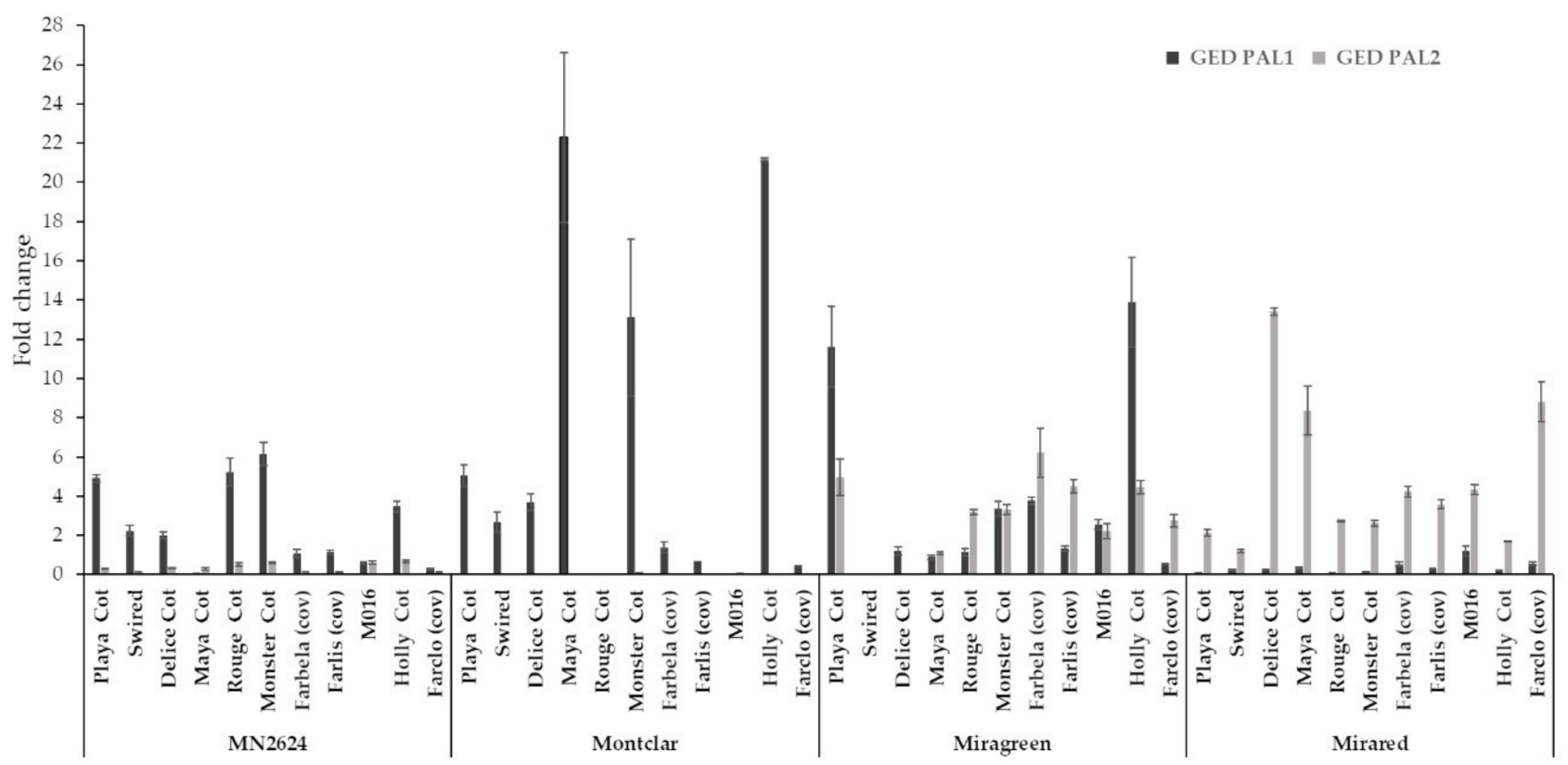

Figure 5. Expression profiles of PAL genes (PAL1 and PAL2) from 11 different apricot cultivars grafted on four different rootstocks (A'MN2624', 'Montclar', 'Miragreen', and 'Mirared)'. Evaluating the effect of every combination three months after grafting. Values are the mean of three replicates $\pm \mathrm{SE}$.

\subsection{Plant Growth Related Variables and Anatomical Characterization One Year after Grafting}

Stem diameters at the graft interface and leaf area were measured one year after grafting in all graft combinations. Whereas not significant differences were observed for stem diameters among the different scion-rootstock combinations (data not shown), differences in leaf area on grafted apricot cultivars were obtained. The results showed that $62 \%$ of the cultivars had differences depending on the rootstock used (Figure 6). 'Montclar' and 'Miragreen' were the rootstocks that provided the higher leaf area in $46 \%$ and $38 \%$ of the apricot cultivars, respectively, compared to 'Mirared' and 'MN2624' (with only $8 \%$ of cultivars with high values). The cv. 'Playa Cot' grafted on 'Miragreen' and 'Farbela (cov)' grafted on 'Montclar' had the highest values of the leaf area.

Anatomic studies of the graft interface were performed following the five graft categories (A, B, C, D, and E) established by Herrero (1951). In this classification, the established categories ranged from ' $A$ ', which represents a perfect union, to ' $E^{\prime}$, which represents broken grafts. Thus, using this classification, the most compatible combinations were formed by 'Miragreen' and 'Mirared' with $91 \%$ and $84 \%$ of unions classified in ' $\mathrm{A}$ ' and 'B, respectively (Figure 7). It is noteworthy to point out that 'Mirared' and Miragreen' showed good compatibility with the exigent cv. 'Moniqui'. On the other side, wood and bark discontinuities (categories ' $\mathrm{C}^{\prime}$ and ' $\mathrm{D}$ ') were frequently observed with the rootstocks 'Montclar' and 'MN2624'. 'Montclar' exhibited 58\% of graft unions included in B category, 38\% between 'C-D', and $4 \%$ in ' $\mathrm{E}$ '. Likewise, 'MN2624' exhibited 57\% compatibility ('A' and 'B') and $43 \%$ of incompatibility ( $38 \%$ between ' $\mathrm{C}-\mathrm{D}^{\prime}$ ' and $5 \%$ ' $\mathrm{E}$ '). Graft combinations classified within the ' $C$ ' category can progress to an eventual 'localized' incompatibility in the long term. The most exigent cultivars with a greater tendency to express graft incompatibility grafted on 'MN2624' were 'Moniqui', 'Monster Cot', and 'Maya Cot', 'Moniqui' and 'Delice Cot' in 'Montclar', 'Rouge Cot' and 'Monster Cot' in 'Miragreen', and 'Farclo (cov)' and 'Playa Cot' in 'Mirared'. 

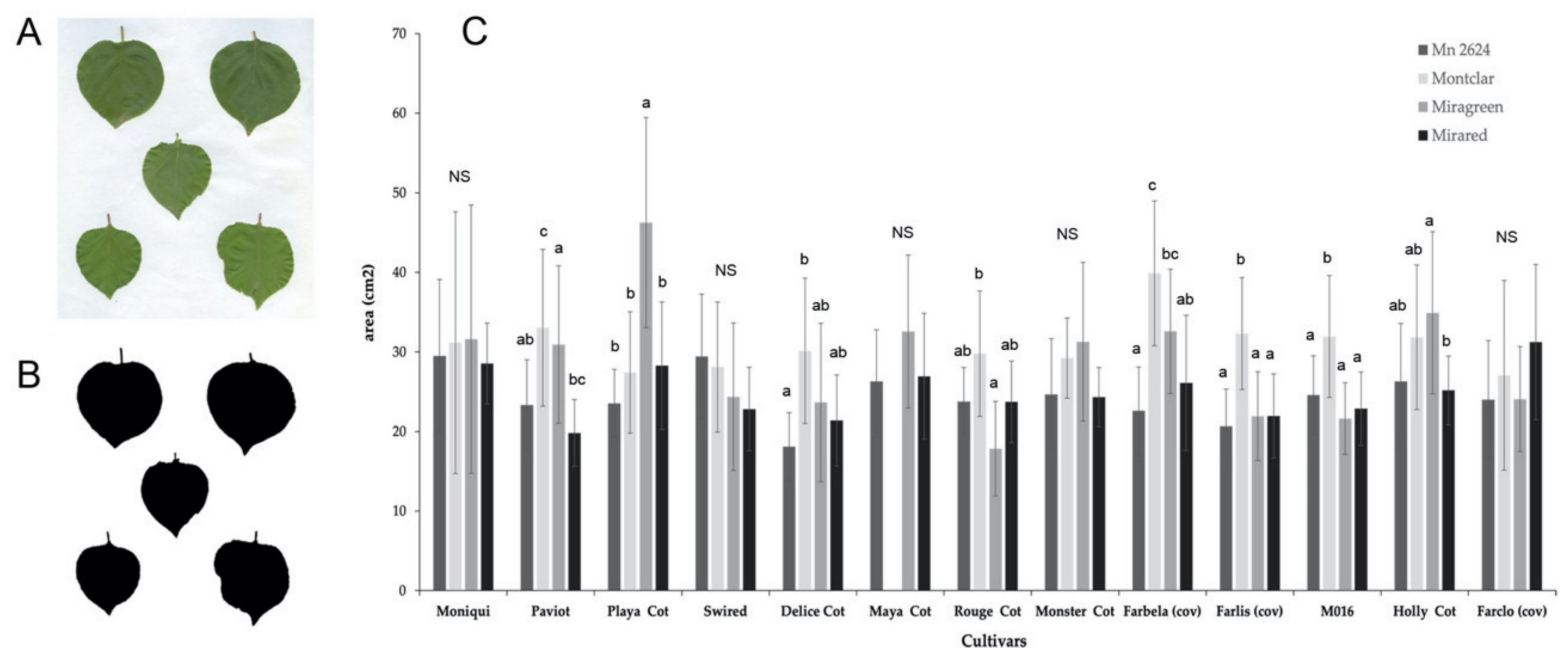

Figure 6. Effect of graft combinations on leaf area from 13 apricot cultivars grafted on four rootstocks ('MN2624', 'Montclar', 'Miragreen', and 'Mirared') one year after grafting. (A) Original leaves images from the graft combination 'Paviot grafted on Montclar', (B) image converted to black and white from ImageJ, which computes the total area of all leaves. (C) Graphical representation of the average of 10 leaves chosen randomly from the middle zone of three replicates of each cultivar for each rootstock. Values are means $\pm \mathrm{SE}$ of three replicates. Different letters indicate significant differences at $p<0.05$ within each cultivar for different rootstocks according to Tukey test; 'NS' indicates non-significant differences.

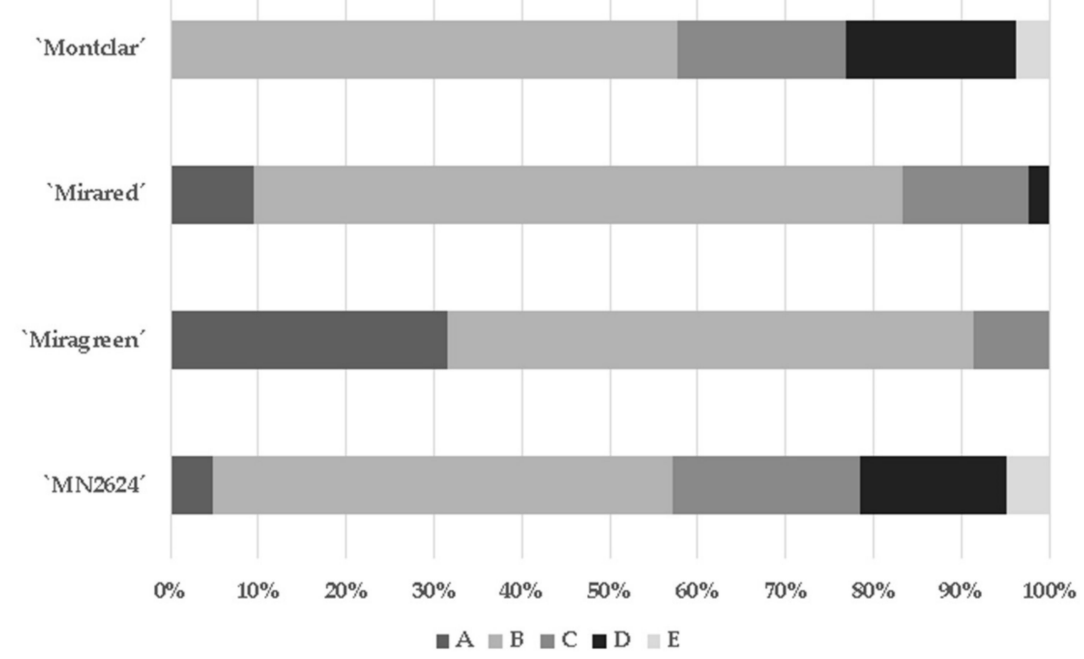

Figure 7. Internal characterization of the graft unions for each rootstock based on the Herrero classification (1951). Graphic represents the proportion (\%) of the category A to E detected per graft combinations.

\subsection{Correlation beetwen Traits and Pricipal Components Analysis (PCA)}

Statistical correlation analyses were performed combining the results obtained from the physiological, molecular, and anatomic characterization at 42 days, 3 months, and 1 year after grafting. Significant positive Pearson correlation existed between the phenotypic parameters (Table S1, Figure 8A) observed at the same and different developmental stages. Graft take was positively related with graft length and number of leaves at 3 months after grafting ( $\mathrm{r}=0.567$ and $0.532 ; p \leq 0.01, n=52)$ and negatively correlated with graft interface diameter at one year after grafting $(\mathrm{r}=-0.308 ; p \leq 0.05, n=52)$. Cell arrangement was positively and significantly correlated with cell proliferation at 42 DAG and graft interface diameter at one year after grafting $(r=0.783$ and $0.582 ; p \leq 0.001, n=52$. However, a negative correlation was found between cell proliferation and cell arrangement with necrotic line at $42 \mathrm{DAG}(\mathrm{r}=-0.776$ and $-0.669 ; p \leq 0.01, n=52)$. By three months 
after grafting, graft length was strongly correlated with number of leaves $(\mathrm{r}=0.714$; $p \leq 0.01, n=52$ ). Likewise, the PAL2 gene was weakly but positively correlated with cell arrangement and graft interface diameter at one year after grafting $(\mathrm{r}=0.312$ and $0.308 ; p \leq 0.05, n=48$ ). Interestingly, a weak but significantly negative correlation was found between graft length 3 months after grafting and graft interface diameter one year after grafting $(\mathrm{r}=-0.290 ; p \leq 0.05, n=52)$ and between necrotic line at 42DAG and graft interface diameter at one year after grafting $(\mathrm{r}=-0.325 ; p \leq 0.05, n=52)$. No correlation was found between leaf area measured one year after grafting with the rest of the histological and molecular parameters evaluated.

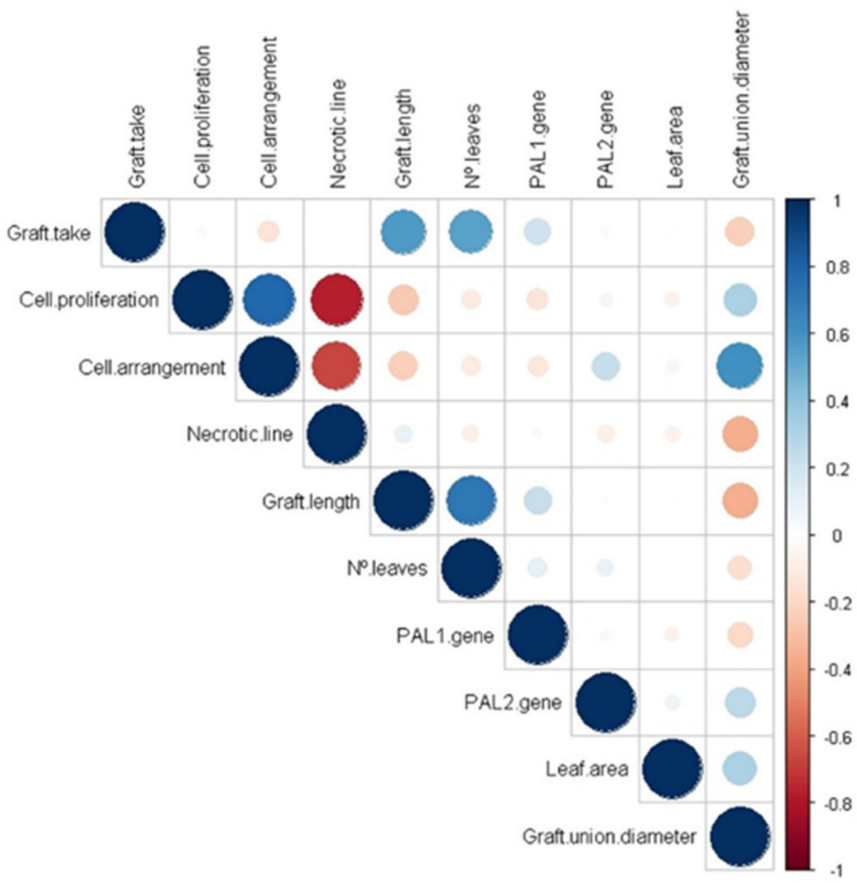

A

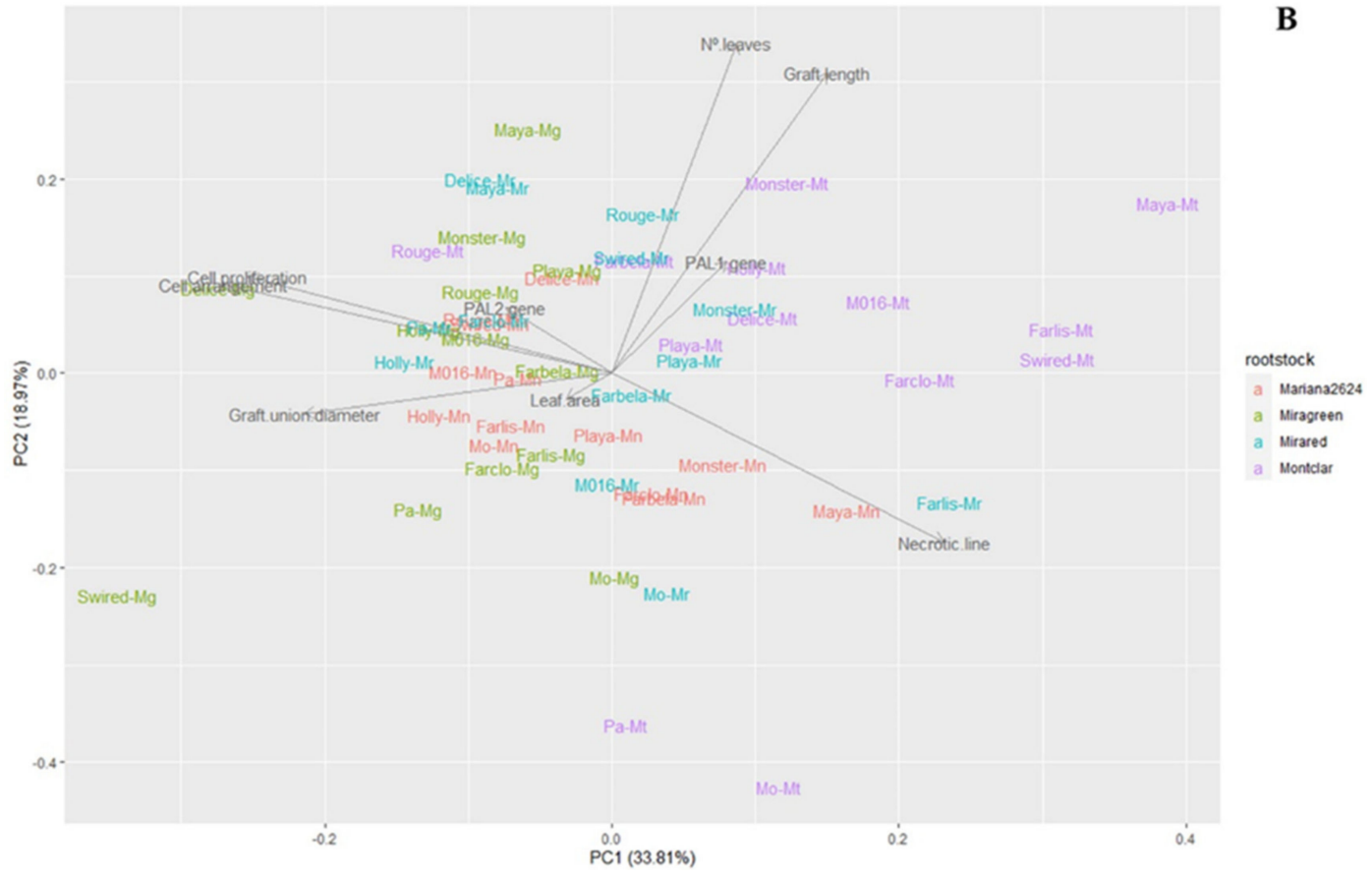

Figure 8. Pearson's correlation coefficient (A) and principal component analysis (PCA) (B) for the traits studied in all combinations at 42 days, three months, and one year after grafting. In PCA, the colors are determinated by the rootstocks (green 'Mg' = 'Miragreen', purple 'Mt' = 'Montclar', blue 'Mr' = 'Mirared', red 'Mn' = 'MN2624'). 
PCA was done in order to gain insights about the real contribution of the histological, molecular, and vegetative parameters evaluated related to the graft (in)compatibility trait. Principal components analysis (PCA) was done on all physiological and molecular variables of all graft combinations studied. The first two principal components (PCs) accounted for $53 \%$ of the total variance, with $34 \%$ explained by PC1 and $19 \%$ by PC2. Eigenvectors represent the strength (given by the length of the vector) and direction of the trait correlation relative to the first two principal components. Data showed that samples were separated along PC1 according to the different rootstocks, with most of the 'Miragreen' combinations on the negative side and 'Montclar' on the positive side. A large number of graft combinations formed by 'Miragreen' and 'Mirared' were grouped together, and the most genetically distant rootstock appeared distant. Likewise, the rootstock 'Montclar' that displayed the worse physiological and molecular compatibility data compared to the other rootstocks lined up with the necrotic line, graft length, and PAL1 gene traits. However, 'Miragreen' and 'Mirared' were situated between the more relevant physiological traits associated with graft compatibility: cell proliferation and cell arrangement and PAL 2 gene.

\section{Discussion}

New apricot cultivars (Prunus armeniaca L.) and rootstocks for apricot are being introduced through commercial nurseries. However, experience has shown that extensive testing of the graft behavior of these combinations at early stages of development is critical to avoid commercial failures due to the late manifestation of localized graft incompatibility problems between the grafting partners [21].

In this study, we phenotyped the graft compatibility of 13 apricot cultivars grafted on different Prunus rootstocks with different genetic backgrounds: 'Miragreen' (P. cerasifera $\times$ P. davidiana), 'Mirared' (P. cerasifera $\times$ Nemared), 'Marianna 2624' (P. cerasifera $\times$ P. munsoniana), and 'Montclar' (P. persica seedlings). The problems of graft compatibility of the rootstock 'MN2624' with a lot of apricot cultivars are widely known but not with the cultivars evaluated in this study. Likewise, the graft compatibility with the other rootstocks used for apricot in Aragon is unknown. The analysis was carried out at early stages of development using different approaches:cytomorphological analysis at 42 DAG, PAL molecular expression analysis at 3 months after grafting, and anatomic characterization one year after grafting. For the rootstocks genetically distant from Prunus armeniaca L., more attention was necessary for the graft compatibility evaluation, unlike other species of stone fruits and interspecific hybrids that may have good compatibility with a lot of cultivars [10,13].

It is widely known that the first step of graft union development, callus formation, is an important step that determines the establishment of a successful union [24,54]. In this work, differences in callus cell proliferation, cell arrangement, and cellular shape were found between compatible and incompatible combinations in agreement with other studies $[19,20,24,55]$. This stage is very important since more compact and more regular callus cells are relevant to promote the complete cambium continuity and vascular differentiation [42,56,57]. By 42 DAG, our results revealed that the rootstocks 'Miragreen' and 'Mirared' showed better cell development, taking into account the different histological characteristics evaluated with a higher percentage of apricot cultivars, compared to the other plum hybrid rootstock 'MN2624' and 'Montclar'. This is in agreement with the fact that relatedness of species was not a good predictor of graft compatibility, since vascular reconnection can occur between distantly related species and can fail to occur in some more closely related species [58].

Several studies reported that the rootstock influences the most important attributes of the trees, such as vegetative growth, productivity, fruit quality, and modulation of scion phenotypes $[9,11]$. To evaluate the effect of the rootstock in the initial growth of the bud, we measured the graft length 3 months after grafting. 'MN2624' demonstrated weaker apricot growth and 'Montclar' higher compared to the other rootstocks. 'Miragreen' and 'Mirared' had an intermediate growth. This initial growth capacity of the scion determines the vigor of the tree and the plantation establishment. Nowadays, a higher density planting of trees 
is a trend in apricot cultivation. Furthermore, smaller trees are easier to handle and have reduced production costs, meanwhile increasing per-acre productivity $[59,60]$. In relation to this parameter with graft (in)compatibility, some studies have reported that the excessive growth rate during the first year can cause breakage at the point of the union [61]. Hence, it might be the case of 'Montclar', which exhibited a greater growth but the graft success rate was low compared to the other rootstocks. Despite Prunus Persica L. rootstocks have been widely used for apricot, it has been reported that peach rootstocks display variable compatibility with apricot cultivars, exhibiting good compatibility only with less exigent cultivars [62].

In addition, the monitoring of Phenylalanine ammonia-lyase (PAL) activity and gene expression have already been proposed and applied as markers for the early detection of incompatible graft combinations (reviewed by Loupit and Cookson [29], Assunção [31]). PAL genes that encode key enzymes in the phenylpropanoid pathway were shown to be differentially regulated between compatible and incompatible grafts, suggesting their involvement in the incompatibility phenomenon $[30,32,33,53]$. In this study, our findings displayed that there was an increase of PAL 1 for the apricot cultivars grafted on the rootstocks 'MN2624' and 'Montclar' greater than for cultivars grafted on 'Miragreen' and 'Mirared'. Two PAL genes have been identified in apricot, ParPAL1 and ParPAL2 [33]. In previous works, ParPAL1 was more highly expressed in incompatible apricot in vitro callus grafts at early stages of development in comparison to compatible combinations [33]. Additionally, it was suggested the involvement of ParPAL1 in the synthesis of flavonoids. Overall, in this work, the cultivars that presented a higher PAL1 expression were considered as exigent cultivars. Interestingly, 'Mirared' presented a completely different profile showing a higher PAL2 expression that could be related to better lignification.

Graft union diameter were unaffected by the cultivar or the scion-rootstock combination used, whereas leaf area was a parameter that showed remarkable differences between scion-rootstock combinations one year after grafting. The effect of the rootstock has been described in different species-on the leaf area, morphology, growth, biomass, and photosynthesis of the grafted plant $[63,64]$. More recently, it has been suggested that the restriction of leaf area may result from inhibition of net photosynthesis, which decreases the availability of assimilates for leaf growth. In this work, increases in leaf area have not been reflected in a greater graft compatibility for a given graft combination or vice versa (e.g., cv 'Playa cot' grafted on 'Miragreen' showed 50\% incompatibility values and had the greatest leaf area for this rootstock). However, it should be addressed in the future if the greatest leaf area associated to 'Montclar' and 'Miragreen' could be associated to an increase in the crop yield.

Rootstocks for apricots can be divided into two groups, one well compatible 'with a wide range of cultivars', and the other having affinity 'only with a certain range of grafted cultivars'. In this sense, the analysis based at the anatomic level confirmed the histological and molecular analysis classifying the 'Miragreen' and 'Mirared' rootstocks as more compatible and 'Montclar' and 'MN2624' as less compatible. Concerning the correlations found between the different parameters evaluated, a strong and positive correlation was found between cytomorphological characteristics (cell proliferation vs. cell arrangement at $42 \mathrm{DAG}$ ) and a negative correlation between necrotic line and cytomorphological characteristics (cell proliferation and cell arrangement) and graft interface diameter, as was also reported by Irisarri [45]. Regarding the vegetative parameters (graft length and number of leaves), these were positively correlated with graft take $(\mathrm{r}=0.567$ and $0.532 ; p \leq 0.01, n=52)$. In addition, significant positive correlations existed between the phenotypic parameters observed at different developmental stages. Cell arrangement 42 DAG vs. PAL2 expression three months after grafting $(\mathrm{r}=0.312 ; p \leq 0.05, n=48)$ and cell arrangement $42 \mathrm{DAG}$ vs. graft interface diameter interface one year after grafting $(\mathrm{r}=0.582 ; p \leq 0.001, n=52)$ suggests that early predictions can anticipate the fate of a graft combination. However, we did not observe a correlation of graft take with physiological or molecular parameters related to graft compatibility. In this work, apricot cultivars grafted on the incompatible rootstocks 
'MN2624' and 'Montclar' exhibited a higher graft take rate than the compatible rootstocks 'Miragreen' and 'Mirared' (81\% and 78\% vs. 62\% and 75\%, respectively). Our results are in agreement with other studies on woody plants, in which graft success was not correlated with graft take [14]. Although correlations were found between PAL1 and PAL2 isoforms in peach/plum graft combinations (above and below the graft union) three years after grafting [30], no relationships were detected between the isoforms at the graft interface of the different apricot/Prunus combinations studied three months after grafting. Likewise, rootstock-mediated changes in leaf area were not correlated with cytomorphological or molecular traits associated to graft incompatibility.

\section{Conclusions}

The knowledge of scion-rootstock graft compatibility is an indispensable prerequisite before releasing any cultivar or rootstock into the market for commercial use. In this study, different approaches involved in the graft response have been evaluated in new cultivars and rootstocks combinations. Vegetative growth parameters (graft length, leaf area, and graft interface diameter) were not informative to evaluate graft incompatibility between the different new apricot cultivars grafted on the Prunus rootstocks evaluated ('MN2624', 'Miragreen', 'Mirared', and 'Montclar'). Graft length depended on the graft type and suggested an influence of the rootstock used in the scion's growth three months after grafting. The results showed that apricot cultivars grafted on 'Montclar' appeared to induce a higher vigor than in the rootstocks 'MN2624', 'Miragreen', and 'Mirared'. On the contrary, physiological (cell proliferation, cell arrangement, and necrotic line), molecular (PAL1 expression), and anatomical (bark and wood discontinuities) analysis proved to be a more sensitive indicator of lack of adaptation between both graft partners. Concerning cell proliferation and cell arrangement degree in the studied graft combinations, a significantly higher cell callus proliferation was detected in the apricot cultivars grafted on 'Miragreen' at 42 DAG. In parallel, an induction of PAL1 gene was detected in incompatible combinations three months after grafting. Taken as a whole, 'Miragreen' and 'Mirared' showed the highest degree of compatibility with more than $90 \%$ of the apricot cultivars. Regarding the apricot cultivar, our findings allowed us to identify four cultivars ('Paviot', 'Farbela (cov)',

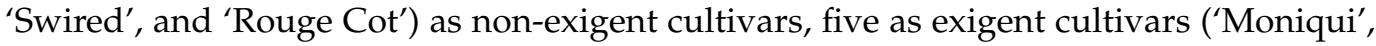
'Playa Cot', 'Maya Cot', 'Monster Cot', and 'M016'), and four with intermediate compatibility depending on the rootstock. In summary, 'Miragreen' and 'Mirared' have proven to be promising rootstocks for apricot cultivation to avoid graft incompatibility problems. This information will be valuable for nurseries and growers for planting the best scion-rootstock combination in commercial orchards. More studies must be addressed to evaluate the agronomic performance of these rootstocks grown in our Mediterranean conditions.

Supplementary Materials: The following are available online at https://www.mdpi.com/article/10 .3390/agronomy11081464/s1, Table S1: Pearson correlations coefficients of all parameters studied at different developmental stages after grafting. At 42 DAG (microscopy observations), 3 months after grating (graft length, $\mathrm{n}^{\mathrm{o}}$ leaves, gene expression of PAL), and one year after grafting (area of leaves and graft union diameter).

Author Contributions: Investigation, conceptualization, and writing-review and editing, P.I., P.E., and A.P.; methodology, P.I. and A.P.; validation, P.I. and A.P.; formal analysis, P.I.; data curation, P.I.; writing-original draft preparation, P.I. and A.P.; visualization, P.I.; project administration, resources, supervision, and funding acquisition, A.P. All authors have read and agreed to the published version of the manuscript.

Funding: This research was funded by the Instituto Nacional de Investigación y Tecnología Agraria y Alimentaria (INIA), grants numbers RTA2015-00046 and RFP2015-00015 and the Gobierno de Aragón-European Social Fund, European Union (Grupo Consolidado A12), and The APC funded by Gobierno de Aragón-European Social Fund, European Union (Grupo Consolidado A12).

Institutional Review Board Statement: Not applicable.

Informed Consent Statement: Not applicable. 
Data Availability Statement: The data presented in this study are available in article.

Acknowledgments: The authors thank Rosa Fustero and María García for technical assistance. We gratefully acknowledge MARIANO SORIA S.L. nursery for providing and managing the plant material used in this study.

Conflicts of Interest: The authors declare no conflict of interest. The funders had no role in the design of the study; in the collection, analyses, or interpretation of data; in the writing of the manuscript, or in the decision to publish the results.

\section{References}

1. FAO Food and Agriculture Organization of the United Nations. Available online: http://www.fao.org/faostat/es/\#data/QC (accessed on 12 February 2020).

2. Zhebentyayeva, T.; Ledbetter, C.; Burgos, L.; Llácer, G. Apricot. In Fruit Breeding; Badenes, M.L., Byrne, D.H., Eds.; Springer: Boston, MA, USA, 2012; pp. 415-458, ISBN 978-1-4419-0762-2.

3. Krška, B. Genetic Apricot Resources and their Utilisation in Breeding. In Breeding and Health Benefits of Fruit and Nut Crops; Soneji, J., Nageswara-Rao, M., Eds.; InTech: London, UK, 2018; Volume i, pp. 63-82. [CrossRef]

4. Herrera, S.; Lora, J.; Hormaza, J.I.; Herrero, M.; Rodrigo, J. Optimizing Production in the New Generation of Apricot Cultivars: Self-incompatibility, S-RNase Allele Identification, and Incompatibility Group Assignment. Front. Plant Sci. 2018, 9, 1-12. [CrossRef] [PubMed]

5. Krška, B.; Vachůn, Z. Apricot breeding at the Faculty of Horticulture in Lednice. Agronomy 2016, 6, 27. [CrossRef]

6. Llácer, G. Problemática actual de la mejora genética de frutales en España. ITEA 2005, 101, 364-372.

7. Egea, J.; Dicenta, F.; Burgos, L.; Martínez-Gómez, P.; Rubio, M.; Campoy, J.A.; Ortega, E.; Patiño, J.L.; Nortes, L.; Molina, A.; et al New apricot cultivars from CEBAS-CSIC (Murcia, Spain) breeding programme. Acta Hortic. 2010, 862, 113-118. [CrossRef]

8. Bassi, D.; Audergon, J.M. Apricot Breeding: Update and Perspectives. In Proceedings of the Acta Horticulturae, International Society for Horticultural Science (ISHS), XIIth Symposium on Apricot, Avignon, France, 10-14 September 2001; International Society for Horticultural Science: Leuven, Belgium, 2006; pp. 279-294. Available online: https://www.ishs.org/ishs-article/701_ 43 (accessed on 10 April 2021).

9. Rasool, A.; Mansoor, S.; Bhat, K.M.; Hassan, G.I.; Baba, T.R.; Alyemeni, M.N.; Alsahli, A.A.; El-Serehy, H.A.; Paray, B.A.; Ahmad, P. Mechanisms Underlying Graft Union Formation and Rootstock Scion Interaction in Horticultural Plants. Front. Plant Sci. 2020, 11. [CrossRef]

10. Southwick, S.M.; Weis, K.G. Selecting and propagating rootstocks to produce apricots. Horttechnology 1998, 8, 164-170. [CrossRef]

11. Warschefsky, E.J.; Klein, L.L.; Frank, M.H.; Chitwood, D.H.; Londo, J.P.; von Wettberg, E.J.B.; Miller, A.J. Rootstocks: Diversity, Domestication, and Impacts on Shoot Phenotypes. Trends Plant Sci. 2016, 21, 418-437. [CrossRef]

12. Bassi, D.; Bartolini, S.; Viti, R. Recent Advances on enviromental and physiological challenges in apricot growing. Acta Hortic. 2006, 717, 23-31. [CrossRef]

13. Reig, G.; Zarrouk, O.; Font i Forcada, C.; Moreno, M.Á. Anatomical graft compatibility study between apricot cultivars and different plum based rootstocks. Sci. Hortic. 2018, 237, 67-73. [CrossRef]

14. Hartmann, H.T.; Kester, D.E.; Davies, F.T.; Geneve, R.L. Principles of grafting and budding. In Plant Propagation. Principles and Practices; Education, P., Ed.; Prentice Hall: New York, NY, USA, 2002; pp. 411-460.

15. Pina, A.; Errea, P. A review of new advances in mechanism of graft compatibility-incompatibility. Sci. Hortic. 2005, 106, 1-11. [CrossRef]

16. Aloni, B.; Cohen, R.; Karni, L.; Aktas, H.; Edelstein, M. Hormonal signaling in rootstock-scion interactions. Sci. Hortic. 2010, 127, 119-126. [CrossRef]

17. Errea, P.; Felipe, A.J. Compatibilidad de injerto en albaricoquero (Prunus armeniaca). Investig. Agrar. Prod. Protección Veg. 1993, 8, 67-77.

18. Lapins, K. Some symptoms of stock-scion incompatibility of apricot varieties on peach seedling rootstock. Can. J. Plant Sci. 1959, 39, 194-203. [CrossRef]

19. Errea, P.; Felipe, A.J.; Herrero, M. Graft establishment between compatible and incompatible Prunnus spp. J. Exp. Bot. 1994, 45, 393-401. [CrossRef]

20. Ermel, F.F.; Posëssel, J.L.; Faurobert, M.; Catessons, A.M. Early Scion/Stock Junction in Compatible and Incompatible Pear/Pear and Pear/Quince Grafts: A Histo-cytological Study. Ann. Bot. 1997, 79, 505-515. [CrossRef]

21. Pina, A.; Cookson, S.; Calatayud, A.; Trinchera, A.; Errea, P. Physiological and molecular mechanisms underlying graft compatibility. In Vegetable Grafting: Principles and Practices; Colla, G., Perez-Alfocea, F., Schwarz, D., Eds.; CABI Publising: London, UK, 2017; pp. 132-154, ISBN 978-1-78064-897-2.

22. Soumelidou, K.; Battey, N.H.; Jhon, P.; Barnett, J.R. The Anatomy of the developing bud union and its relationship to dwarfing in apple. Ann. Bot. 1994, 74, 605-611. [CrossRef]

23. Pina, A.; Errea, P.; Schulz, A.; Martens, H.J. Cell-to-cell transport through plasmodesmata in tree callus cultures. Tree Physiol. 2009, 29, 809-818. [CrossRef] 
24. Errea, P.; Garay, L.; Marín, J.A. Early detection of graft incompatibility in apricot (Prunus armeniaca) using in vitro techniques. Physiol. Plant 2001, 112, 135-141. [CrossRef]

25. Trinchera, A.; Pandozy, G.; Rinaldi, S.; Crinò, P.; Temperini, O.; Rea, E. Graft union formation in artichoke grafting onto wild and cultivated cardoon: An anatomical study. J. Plant Physiol. 2013, 170, 1569-1578. [CrossRef]

26. Irisarri, P.; Binczycki, P.; Errea, P.; Martens, H.J.; Pina, A. Oxidative stress associated with rootstock-scion interactions in pear/quince combinations during early stages of graft development. J. Plant Physiol. 2015, 176, 25-35. [CrossRef]

27. Pina, A.; Errea, P. Influence of graft incompatibility on gene expression and enzymatic activity of UDP-glucose pyrophosphorylase. Plant Sci. 2008, 174, 502-509. [CrossRef]

28. Aloni, B.; Karni, L.; Deventurero, G.; Levin, Z.; Cohen, R.; Katzir, N.; Lotan-Pompan, M.; Edelstein, M.; Aktas, H.; Turhan, E.; et al. Physiological and biochemical changes at the rootstock-scion interface in graft combinations between Cucurbita rootstocks and a melon scion. J. Hortic. Sci. Biotechnol. 2008, 83, 777-783. [CrossRef]

29. Loupit, G.; Cookson, S.J. Identifying Molecular Markers of Successful Graft Union Formation and Compatibility. Front. Plant Sci. 2020, 11, 1-11. [CrossRef] [PubMed]

30. Amri, R.; Font i Forcada, C.; Giménez, R.; Pina, A.; Moreno, M.Á. Biochemical Characterization and Differential Expression of PAL Genes Associated With “Translocated" Peach/Plum Graft-Incompatibility. Front. Plant Sci. 2021, 12. [CrossRef] [PubMed]

31. Assunção, M.; Tedesco, S.; Fevereiro, P. Molecular Aspects of Grafting in Woody Plants. Annu. Plant Rev. 2021, 4. [CrossRef]

32. Dos Santos Pereira, I.; Silva Messias, R.; Diniz Campos, Â.; Errea, P.; Corrêa Antunes, L.E.; Fachinello, J.C.; Pina, A. Growth characteristics and phenylalanine ammonia-lyase activity in peach grafted on different Prunus spp. Biol. Plant 2014, 58, 114-120. [CrossRef]

33. Irisarri, P.; Zhebentyayeva, T.; Errea, P.; Pina, A. Differential expression of phenylalanine ammonia lyase (PAL) genes implies distinct roles in development of graft incompatibility symptoms in Prunus. Sci. Hortic. 2016, 204, 16-24. [CrossRef]

34. Kao, Y.-Y.; Harding, S.A.; Tsai, C.-J. Differential expression of two distinct phenylalanine ammonia-lyase genes in condensed tannin-accumulating and lignifying cells of quaking aspen. Plant Physiol. 2002, 130, 796-807. [CrossRef]

35. Kumar, A.; Ellis, B.E. The phenylalanine ammonia-lyase gene family in raspberry. Structure, expression, and evolution. Plant Physiol. 2001, 127, 230-239. [CrossRef]

36. Lillo, C.; Lea, U.S.; Ruoff, P. Nutrient depletion as a key factor for manipulating gene expression and product formation in different branches of the flavonoid pathway. Plant. Cell Environ. 2008, 31, 587-601. [CrossRef] [PubMed]

37. Errea, P. Implications of phenolic compounds in graft incompatibility in fruit tree species. Sci. Hortic. 1998, 74, 195-205. [CrossRef]

38. Canas, S.; Assunção, M.; Brazão, J.; Zanol, G.; Eiras-Dias, J.E. Phenolic compounds involved in grafting incompatibility of vitis spp: Development and validation of an analytical method for their quantification. Phytochem. Anal. 2015, 26, 1-7. [CrossRef] [PubMed]

39. Usenik, V.; Krška, B.; Vičan, M.; Štampar, F. Early detection of graft incompatibility in apricot (Prunus armeniaca L.) using phenol analyses. Sci. Hortic. 2006, 109, 332-338. [CrossRef]

40. Hudina, M.; Primoz, O.; Jakopic, J.; Stampar, F. The phenolic content and its involvement in the graft incompatibility process of various pear rootstocks (Pyrus communis L.). J. Plant Physiol. 2014, 171, 76-84. [CrossRef] [PubMed]

41. Zheng, B.S.; Chu, H.L.; Jin, S.H.; Huang, Y.J.; Wang, Z.J.; Chen, M.; Huang, J.Q. cDNA-AFLP analysis of gene expression in hickory (Carya cathayensis) during graft process. Tree Physiol. 2010, 30, 297-303. [CrossRef]

42. Cookson, S.J.; Clemente Moreno, M.J.; Hevin, C.; Nyamba Mendome, L.Z.; Delrot, S.; Trossat-Magnin, C.; Ollat, N. Graft union formation in grapevine induces transcriptional changes related to cell wall modification, wounding, hormone signalling, and secondary metabolism. J. Exp. Bot. 2013, 64, 2997-3008. [CrossRef]

43. Pina, A.; Irisarri, P.; Errea, P.; Zhebentyayeva, T. Mapping Quantitative Trait Loci Associated With Graft (In) Compatibility in Apricot (Prunus armeniaca L.). Front. Plant Sci. 2021, 12. [CrossRef] [PubMed]

44. Williams, J.H.; Friedman, W.E.; Arnold, M.L. Developmental selection within the angiosperm style: Using gamete DNA to visualize interspecific pollen competition. Proc. Natl. Acad. Sci. USA 1999, 96, 9201-9206. [CrossRef] [PubMed]

45. Irisarri, P.; Zhebentyayeva, T.; Errea, P.; Pina, A. Inheritance of self- and graft-incompatibility traits in an F1 apricot progeny. PLoS ONE 2019, 14, e0216371. [CrossRef] [PubMed]

46. Meisel, L.; Fonseca, B.; González, S.; Baeza-Yates, R.; Cambiazo, V.; Campos, R.; Gonzalez, M.; Orelana, A.; Retameles, J.; Silva, H. A Rapid and Efficient Method for Purifying High Quality Total RNA from Peaches (Prunus persica) for Funtional Genomics Analyses. Biol. Res. 2005, 38, 83-88. [CrossRef]

47. Ruijter, J.M.; Ramakers, C.; Hoogaars, W.M.H.; Karlen, Y.; Bakker, O.; van den Hoff, M.J.B.; Moorman, A.F.M. Amplification efficiency: Linking baseline and bias in the analysis of quantitative PCR data. Nucleic Acids. Res. 2009, 37, e45. [CrossRef] [PubMed]

48. Schefe, J.H.; Lehmann, K.E.; Buschmann, I.R.; Unger, T.; Funke-Kaiser, H. Quantitative real-time RT-PCR data analysis: Current concepts and the novel "gene expression's CT difference" formula. J. Mol. Med. 2006, 84, 901-910. [CrossRef] [PubMed]

49. Jiménez, S.; Li, Z.; Reighard, G.L.; Bielenberg, D.G. Identification of genes associated with growth cessation and bud dormancy entrance using a dormancy-incapable tree mutant. BMC Plant Biol. 2010, 10, 25. [CrossRef]

50. Katabuchi, M. LeafArea: An R package for rapid digital image analysis of leaf area. Ecol. Res. 2015, 30, 1073-1077. [CrossRef]

51. Herrero, J. Studies of compatible and incompatible graft combinations with special reference to hardy fruti trees. J. Hort. Sci. 1951, 26, 186-237. [CrossRef] 
52. R Core Team. R Core Team. R: A Language and Enviroment for Statistical Computing, Vienna, Austria. 2019. Available online: https:/ / www.scirp.org/(S(lz5mqp453edsnp55rrgjct55))/reference/ReferencesPapers.aspx?ReferenceID=2631126 (accessed on 10 April 2021).

53. Pina, A.; Errea, P. Differential induction of phenylalanine ammonia-lyase gene expression in response to in vitro callus unions of Prunus spp. J. Plant Physiol. 2008, 165, 705-714. [CrossRef]

54. Zarrouk, O.; Testillano, P.S.; Risueño, M.C.; Moreno, M.Á.; Gogorcena, Y. Changes in Cell/Tissue Organization and Peroxidase Activity as Markers for Early Detection of Graft Incompatibility in Peach/Plum Combinations. J. Am. Soc. Hortic. Sci. 2010, 135, 9-17. [CrossRef]

55. Espen, L.; Cocucci, M.; Sacchi, G.A. Differentiation and functional connection of vascular elements in compatible and incompatible pear/quince internode micrografts. Tree Physiol. 2005, 25, 1419-1425. [CrossRef]

56. Pina, A.; Errea, P.; Martens, H.J. Graft union formation and cell-to-cell communication via plasmodesmata in compatible and incompatible stem unions of Prunus spp. Sci. Hortic. 2012, 143, 144-150. [CrossRef]

57. Miller, H.; Barnett, J.R. The structure and composition of bead-like projections on Sitka spruce callus cells formed during grafting and in culture. Ann. Bot. 1993, 72, 441-448. [CrossRef]

58. Wulf, K.E.; Reid, J.B.; Foo, E. What drives interspecies graft union success? Exploring the role of phylogenetic relatedness and stem anatomy. Physiol. Plant 2020, 170, 132-147. [CrossRef] [PubMed]

59. Hartman, H.T.; Kester, D.E.; Davies, F.T.; Geneve, R.G. Principles of grafting and budding. In Hartmann and Kester's Plant Propagation: Principles and Practices; Prentice Hall: Upper Saddle River, NJ, USA, 2011; pp. 415-463.

60. Mudge, K.; Janick, J.; Scofield, S.; Goldschmidt, E.E. A History of Grafting. In Horticultural Reviews; 2009; Volume 35, pp. 437-493, ISBN 9780470593776.

61. Moreno, M.A.; Adrada, R.; Aparicio, J.; BetráN, S. Performance of 'Sunburst' sweet cherry grafted on different rootstocks. J. Hortic. Sci. Biotechnol. 2001, 76, 167-173. [CrossRef]

62. Vachun, Z. Rootstocks for apricot-The current situation and main problems. Acta Hortic. 1995, 384, 459-465. [CrossRef]

63. Martínez-Ballesta, M.C.; Alcaraz-López, C.; Muries, B.; Mota-Cadenas, C.; Carvajal, M. Physiological aspects of rootstock-scion interactions. Sci. Hortic. 2010, 127, 112-118. [CrossRef]

64. Albacete, A.; MartÍnez-AndÚjar, C.; Ghanem, M.E.; Acosta, M.; SÁnchez-Bravo, J.; Asins, M.J.; Cuartero, J.; Lutts, S.; Dodd, I.C.; PÉrez-Alfocea, F. Rootstock-mediated changes in xylem ionic and hormonal status are correlated with delayed leaf senescence, and increased leaf area and crop productivity in salinized tomato. Plant Cell Environ. 2009, 32, 928-938. [CrossRef] 